\title{
Mining Tables from Large Scale HTML Texts
}

\author{
Hsin-Hsi Chen, Shih-Chung Tsai and Jin-He Tsai \\ Department of Computer Science and Information Engincering \\ National Taiwan University \\ Taipei, TAIWAN, R.O.C. \\ E-mail: hh_chen@csic.ntu.cdu.tw
}

\begin{abstract}
Table is a very common presentation scheme, but few papers touch on table extraction in text data mining. This paper focuses on mining tables from large-scale HTML texts. Table filtering, recognition, interpretation, and presentation are discussed. Heuristic rules and cell similarities are employed to identify tables. The F-measure of table recognition is $86.50 \%$. We also propose an algorithm to capture attribute-value relationships among table cells. Finally, more structured data is extracted and presented.
\end{abstract}

\section{Introduction}

Tables, which are simple and easy to use, are very common presentation scheme for writers to describe schedules, organize statistical data, summarize experimental results, and so on, in texts of different domains. Because tables provicle rich information, table acquisition is useful for many applications such as document understanding, question-and-answering, text retrieval, etc. However, most of previous approaches on text data mining focus on text parts, and only few touch on tabular ones (Appelt and Israel, 1997; Gaizauskas and Wilks, 1998; Hurst, 1999a). Of the papers on table extractions (Douglas, Hurst and Quinn, 1995; Douglas and Hurst 1996; Hurst and Douglas, 1997; Ng, Lim and Koo, 1999), plain texts are their targets.

In plain text, writers often use special symbols, e.g., tabs, blanks, dashes, etc., to makc tables. The following shows an example. It depicts book titles, authors, and prices.

$\begin{array}{lll}\text { title } & \text { author } & \text { price } \\ \text { Statistical Language Learning } & \text { E.Charniak } & \$ 30 \\ \text { Cross-Language Information Retricval } & \text { G.Grefenstette } & \$ 115 \\ \text { Natural Language Information Retrieval } & \text { T.Strzalkowski } & \$ 144\end{array}$

When detecting if there is a table in free text, we should disambiguate the uses of the special symbols. That is, the special symbol may be a separator or content of cells. Previous papers employ grammars (Green and Krishnamoorthy, 1995), string-based cohesion measures (Hurst and Douglas, 1997), and lcarning methods ( $\mathrm{Ng}$, Lim and Koo, 1999) to deal with table recognition.

Because of the simplicity of table construction methods in free text, the expressive capability is limited. Comparatively, the markup languages like HTML provide very flexible constructs for writers to design tables. The flexibility also shows that table extraction in HTMI texts is harder than that in plain text. Because the HTML texts are huge on the web, and they are important sources of knowledge, it is indispensable to deal with table mining on HTML texts. Hurst (1999b) is the first attempt to collect a corpus from HTML files, $\mathrm{L}^{\wedge} \mathrm{T}_{\mathrm{L}} \mathrm{X}$ files and a small number of ASCII files for table extraction. This paper focuses on HTML texts. We will discuss not only how to recognize tables from HTML texts, but also how to identify the roles of each cell (attribute and/or valuc), and how to utilize the extracted tables.

\section{Tables in HTML}

HTML table begins with an optional caption followed one or more rows. Each row is formed by one or more cells, which are classified into header and data cells. Cells can be merged across rows and columns. The following tags are used:
(1) $<$ table ...></table $>$
(2) $\langle$ tr ... $\rangle<$ tr $\rangle$
(3) $<$ td ... $><$ tdd $>$
(4) $\langle$ th ... $></$ th $>$
(5) $<$ caption ... $><$ caption $>$ 
Table 1. An Example for a Tour Package!

\begin{tabular}{|c|c|c|c|c|}
\hline \multicolumn{3}{|c|}{ Tour Code } & \multicolumn{2}{|c|}{$\left[D 1^{O} 9\right]_{A} A \times 01 \mathrm{AB}$} \\
\hline \multicolumn{3}{|c|}{ Valid } & \multicolumn{2}{|c|}{$1999.04 .01-20000.03 .31$} \\
\hline \multicolumn{3}{|c|}{ Class/lixtension } & Jconomic Class & Extension \\
\hline \multirow{3}{*}{ Adult } & & Single Room & 35,450 & 2,510 \\
\hline & & Double Room & 32,500 & 1,430 \\
\hline & R & lextra Bed & 30,550 & 720 \\
\hline \multirow{3}{*}{ Child } & C & Occupation & 25,800 & 1,430 \\
\hline & & Extra Bed & 23,850 & 720 \\
\hline & & No Occupation & 22,900 & 360 \\
\hline
\end{tabular}

They denote main wrapper, table row, table data, table header, and caption for a table. Table 1 shows an example that lists the prices for a tour. The interprelation of this table in terms of attribute-value relationships is shown as follows:

\begin{tabular}{|c|c|}
\hline Auribule & $\underline{\text { Vallue }}$ \\
\hline Tour Code & DPOL AXOIAB \\
\hline Valid $\quad 190$ & $999.04 .01-2000.03 .3$ \\
\hline Adult-Price-Single Room-licononic Class & 35,450 \\
\hline Adult-price-Double Room-Economic Class & 32,500 \\
\hline Adult-Price-lixtra Bed-1icononic Class & 30,550 \\
\hline Child-price-Occupation-Jconomic Class & 25,800 \\
\hline Child-Ptice-lixlra Bed-Economic Class & $23,8.50$ \\
\hline Child-Price-No Occupration-l conomic Class & 22,900 \\
\hline Adult-l'rice-Single Room-Jixtension & 2,510 \\
\hline Adult-1'rice-Double Room-Jxuension & 1,430 \\
\hline Adult-J'rice-1:xtra Bed-Jixtension & 720 \\
\hline Child-Plice-Oecupation-l ixtension & 1,430 \\
\hline Child-Plice-lixlra Bed-Jixtension & 720 \\
\hline Child-Price-No Occupation-textension & 360 \\
\hline
\end{tabular}

Cell may play the role of attribute and/or value. Several cells may be concatenated to denote an attribute. For example, "Adult-Price-Single Room-Economic Class" means the adult price for economic class and single room. The relationshijes may be read in colmmn wise or in row wise depending on the interpretation. For example, the relationship for "Tour Code:DPOLAXOIAl3" is in row wise. "The prices for "Economic Class" are in column wise.

The table wrapper $(<$ abble $>\ldots<$ table $>$ ) is a useful cue for table recognition. The HTMI, text for the above example is shown as follows. The table tags are enclosed by a table wrapper. sable border

$\forall 1>$

$<t d$ COISSPNAN="3">Tour Colle $</ d \mid$

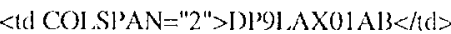
$\langle/ 1>$

$\langle 11>$

$<$ Id COLSP'AN="3">Valid $<$ hd $>$ $\angle$ Id COLSPAN $=" 2 ">1999.04 .01-2000.03 .31</ l d\rangle$ $</ 1>$ $\langle 1>$

1 This example is selected from htp://www.chinaairlines.com/cdpks/los 7-4.htm

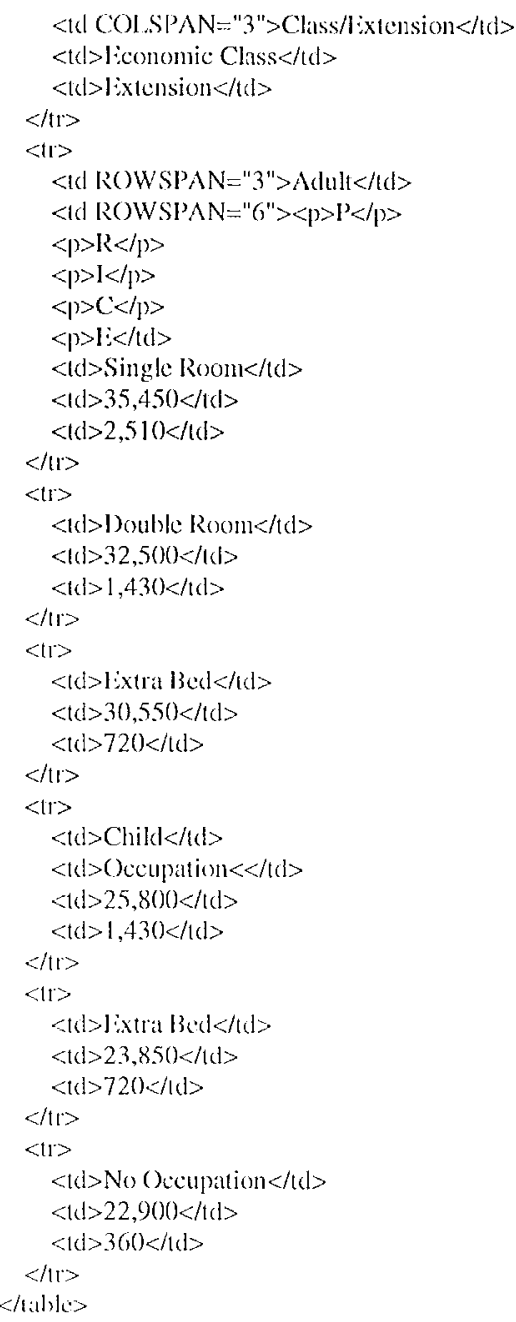

However, a lable does not always exist when lable wrapper appears in HTMI, text. This is because writers often employ table lags to represent form or ment. That allows users to injut queries or make selections.

Another point that should be mentioned is: lable designers usually employ COLSPAN (ROWSPAN) to specily how many columns (rows) a table cell should span. In this example the COI SPAN of cell "Tour Code" is 3. That means "T'our Code" spans 3 columns. Similarly, the ROWSPAN of cell "Adult" is 3. "This cell spans 3 rows. COLSPAN and ROWSPAN provide llexibility for users to design any kinds of tables, but they make attomatic table interpretation more challengeable. 


\section{Flow of Table Mining}

The flow of table mining is shown as Figure 1. It is composed of five modules. Hypertext processing module analyses HTML text, and extracts the table tags. Table filtering module filters out impossible cases by heuristic rules. The remaining candidates are sent to table recognition module for further analyses. The table interpretation module differentiates the roles of cells in the tables. The final module tackles how to present and employ the mining results. The first two modules are discussed in the following paragraph, and the last three modules will be dealt with in the following sections in detail.

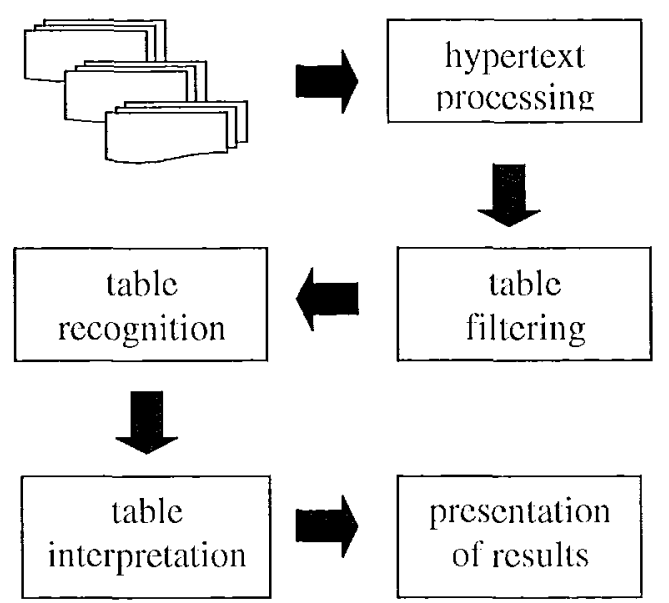

Figure 1. Flow of Table Mining

As specified above, table wrappers do not always introduce tables. Two filtering rules are employed to disambiguate their functions:

(1) A table must contain at least two cells to represent attribute and value. In other words, the structure with only one cell is filtered out.

(2) If the content enclosed by table wrappers contain too much hyperlinks, forms and figures, then it is not regarded as a table.

To evaluate the performance of table mining, we prepare the test data selected from airline information in travelling category of Chinese Yahoo web site (http://www.yahoo.com. tw). Table 2 shows the statistics of our test data.
Table 2. Statistics of Test Data

\begin{tabular}{|c|c|c|c|c|c|c|}
\hline Airlines & $\begin{array}{c}\text { China } \\
\text { Airline }\end{array}$ & $\begin{array}{c}\text { Eva } \\
\text { Airline }\end{array}$ & $\begin{array}{c}\text { Mandarin } \\
\text { Airline }\end{array}$ & $\begin{array}{c}\text { Singapore } \\
\text { Airline }\end{array}$ & $\begin{array}{c}\text { Fareast } \\
\text { Airline }\end{array}$ & Sum \\
\hline $\begin{array}{c}\text { Number of } \\
\text { Pages }\end{array}$ & 694 & 366 & 142 & 110 & 60 & 1372 \\
\hline $\begin{array}{c}\text { \# of } \\
\text { Wrappers }\end{array}$ & 2075 & 568 & 184 & 163 & 228 & $\begin{array}{c}3218 \\
(2.35)\end{array}$ \\
\hline $\begin{array}{c}\text { Number of } \\
\text { Tables }\end{array}$ & 751 & 98 & 23 & 40 & 6 & $\begin{array}{c}918 \\
(0.67)\end{array}$ \\
\hline
\end{tabular}

Table 3. Performance of Filtering Rules

\begin{tabular}{|c|c|c|c|c|c|c|}
\hline & $\begin{array}{c}\text { China } \\
\text { Airline }\end{array}$ & $\begin{array}{c}\text { Eva } \\
\text { Airline }\end{array}$ & $\begin{array}{c}\text { Mandarin } \\
\text { Airline }\end{array}$ & $\begin{array}{c}\text { Singapore } \\
\text { Airline }\end{array}$ & $\begin{array}{c}\text { Fareast } \\
\text { Airline }\end{array}$ & Sum \\
\hline $\begin{array}{c}\text { \# of } \\
\text { wrappers }\end{array}$ & 2075 & 568 & 184 & 163 & 228 & 3218 \\
\hline $\begin{array}{c}\text { Number of } \\
\text { Tables }\end{array}$ & 751 & 98 & 23 & 40 & 6 & 918 \\
\hline $\begin{array}{c}\text { Number of } \\
\text { Non-Tables }\end{array}$ & 1324 & 470 & 161 & 123 & 222 & 2300 \\
\hline $\begin{array}{c}\text { Total } \\
\text { Filter }\end{array}$ & 973 & 455 & 158 & 78 & 213 & 1877 \\
\hline $\begin{array}{c}\text { Wrong } \\
\text { Filter }\end{array}$ & 15 & 0 & 0 & 3 & 2 & 20 \\
\hline $\begin{array}{c}\text { Correct } \\
\text { Rate }\end{array}$ & $98.46 \%$ & $100 \%$ & $100 \%$ & $96.15 \%$ & $99.06 \%$ & $98.93 \%$ \\
\hline
\end{tabular}

These four rows list the names of airlines, total number of web pages, total number of table wrappers, and total number of tables, respectively. On the average, there are 2.35 table wrappers, and 0.67 tables for each web page. The statistics shows that table tags are used quite often in HTML text, and only $28.53 \%$ are actual tables. Table 3 shows the results after we employ the filtering rules on the test data. The $5^{\text {th }}$ row shows how many non-table candidates are filtered out by the proposed rules, and the $6^{\text {th }}$ row shows the number of wrong filters. On the average, the correct rate is $98.93 \%$. Total 423 of 2300 non-tables are remained.

\section{Table Recognition}

After simple analyses specified in the previous section, there are still 423 non-tables passing the filtering criteria. Now we consider the content of the cells. A cell is much shorter than a sentence in plain text. In our study, the length of 43,591 cells (of 61,770 cells) is smaller than 10 characters $^{2}$. Because of the space limitation in a table, writers often use shorthand notations to describe their intention. For

2 A Chinese character is represented by two bytes. That is, a cell contains 5 Chinese characters on the average. 
example, they may use a Chinese character ("到", dao4) to represent at two-character word "到達" (dao4da2, arrive), and a character ("就", li2) to

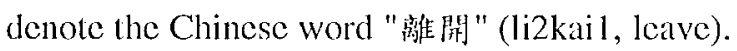
They even employ special symbols like $\boldsymbol{\Delta}$ and $\nabla$ to represent "increase" and "decrease". Thus it is hard to determine if a fragment of HTML text is a table depending on a cell only. The context among cells is important.

Value cells under the same attribute names demonstrate similar concepts. We employ the following metrics to measure the cell similarity.

(1) String similarity

We measure how many characters are common in neighboring cells. If the number is above a theshold, we call the two cells are similar.

(2) Named entity similarity

The metric considers semantics of cells. We adopt some named entity expressions defined in MUC (1998) such as date/time expressions and monetary and percentage expressions. A rule-based method similar to the paper (Chen, Ding, and Tsai, 1998) is employed to tell if a cell is a specific named entity. The neighboring cells belonging to the same named entity catcgory are similar.

(3) Number calcgory similarity

Number characters (0-9) appeal very often. If total number characters in a cell exceeds a threshold, we call the cell belongs to the number category. The neighboring cells in number category are similar.

We count how many neighboring cells are similar. If the percentage is above a threshold, the table tags are interpreted as a table. The data after table filtering (Section 2) is used 10 evaluate the strategies in table recognition. Tables 4-6 show the experimental results when the three metrics are applied incrementally.

Precision rate $(\mathrm{P})$, recall rate $(\mathrm{R})$, and F-measure (F) defined below are adopted to measure the performance.

$P=\frac{\text { NumberOfCorrect TablesSystemGenerated }}{\text { TotalNumberOfTablesSystemGenerated }}$

$$
\begin{gathered}
R=\frac{\text { NumberOfCorrect Tables SystemGenerated }}{\text { TotalNumberOfCorrect Tables }} \\
F=\frac{P+R}{2}
\end{gathered}
$$

Table 4 shows that string similarity camnot capture the similar concept between neighboring cells very well. The F-measure is $55.50 \%$. Table 5 tries to incorporate more semantic features, i.c., categories of named entity. Unfortunately, the result does not meel our expectation. The performance only increases a little. The major reason is that the keywords $(\mathrm{jm} / \mathrm{am}, \$, \%$, etc.) for date/time expressions and monetary and pereentage expressions are usually omitted in table description. Table 6 shows that the F-measure achicves $86.50 \%$ when number calcgory is used. Compared with latbles 4 and 5, the performance is improved

\begin{tabular}{|c|c|c|c|c|c|c|}
\hline & $\begin{array}{l}\text { Chinal } \\
\text { Airline }\end{array}$ & $\begin{array}{l}\text { Jiva } \\
\text { Airline }\end{array}$ & $\begin{array}{c}\text { Mandarin } \\
\text { Airline }\end{array}$ & $\begin{array}{l}\text { Singapore } \\
\text { Airline: }\end{array}$ & $\begin{array}{l}\text { lareast } \\
\text { Airline }\end{array}$ & Sum \\
\hline $\begin{array}{l}\text { Number of } \\
\text { Tables }\end{array}$ & 751 & 98 & 23 & 40 & 6 & 918 \\
\hline $\begin{array}{c}\text { Tábles } \\
\text { Proposed }\end{array}$ & 150 & 41 & 7 & 17 & 5 & 220 \\
\hline Correct & 134 & 39 & 7. & 14 & 3 & 197 \\
\hline $\begin{array}{l}\text { Precision } \\
\text { Rate }\end{array}$ & $89.33 \%$ & $95.12 \%$ & $100 \%$ & $82.35 \%$ & $60 \%$ & $89.55 \%$ \\
\hline Recall Ratte & $17.84 \%$ & $39.80 \%$ & $30.43 \%$ & $3500 \%$ & $50 \%$ & $21.46 \%$ \\
\hline I-measure & $53.57 \%$ & $67.46 \%$ & $6.5 .22 \%$ & $58.68 \%$ & $55 \%$ & $5.5 .50 \%$ \\
\hline
\end{tabular}

Table 4. String Similarity

\begin{tabular}{|c|c|c|c|c|c|c|}
\hline & $\begin{array}{l}\text { China } \\
\text { Airline }\end{array}$ & $\begin{array}{l}\text { Evia } \\
\text { Airline }\end{array}$ & $\begin{array}{c}\text { Mandintin } \\
\text { Airline }\end{array}$ & $\begin{array}{c}\text { Sinciapore } \\
\text { Airline }\end{array}$ & $\begin{array}{l}\text { Jarcist } \\
\text { Airline: }\end{array}$ & Sum \\
\hline $\begin{array}{c}\text { Number of } \\
\text { Tabless }\end{array}$ & 751 & 98 & 23 & 40 & 6 & 918 \\
\hline $\begin{array}{l}\text { T'inbles } \\
\text { Proposed }\end{array}$ & 151 & 42 & 7 & 17 & 5 & 222 \\
\hline & 135 & 40 & 7 & 14 & 3 & 199 \\
\hline $\begin{array}{l}\text { Precision } \\
\text { Rate }\end{array}$ & $89.40 \%$ & $95.24 \%$ & $100 \%$ & $82.35 \%$ & $60 \%$ & $89.64 \%$ \\
\hline Recall Rate & $17.98 \%$ & $40.82 \%$ & $30.43 \%$ & $35.00 \%$ & $50 \%$ & $21.68 \%$ \\
\hline I'meatsure & $53.69 \%$ & $68.03 \%$ & $65.22 \%$ & $58.68 \%$ & $55 \%$ & $55.66 \%$ \\
\hline
\end{tabular}

Table 5. String or Named Entity Similarity

Table 6. String, Named Entity,

\begin{tabular}{|c|c|c|c|c|c|c|}
\hline & $\begin{array}{l}\text { China } \\
\text { Airline } \\
\end{array}$ & $\begin{array}{c}\text { liva } \\
\text { Airline }\end{array}$ & $\begin{array}{c}\text { Mandario } \\
\text { Airline } \\
\end{array}$ & $\begin{array}{c}\text { Singapore } \\
\text { Airline }\end{array}$ & $\begin{array}{l}\text { Fareast } \\
\text { Airline }\end{array}$ & Stım \\
\hline $\begin{array}{c}\text { Number of } \\
\text { Tiables }\end{array}$ & 751 & 98 & 23 & 40 & 6 & 918 \\
\hline $\begin{array}{c}\text { T'ibles } \\
\text { Proposed } \\
\end{array}$ & 668 & 60 & 16 & 41 & 6 & 79)1 \\
\hline Correct & 627 & 58 & 14 & 32 & 4 & 735 \\
\hline $\begin{array}{l}\text { Precision } \\
\text { Rate }\end{array}$ & $93.86 \%$ & $96.67 \%$ & $87.50 \%$ & $78.05 \%$ & $66.67 \%$ & $92.92 \%$ \\
\hline Recall Rate & $83.49 \%$ & $59.18 \%$ & $60.87 \%$ & $80.00 \%$ & $66.67 \%$ & $80.07 \%$ \\
\hline dimeasure & $88.88 \%$ & $77.93 \%$ & $74.19 \%$ & $79.03 \%$ & $66.67 \%$ & $86.50 \%$ \\
\hline
\end{tabular}
or Number Category Similarity 
drastically.

\section{Table Interpretation}

As specificd in Section 1, the attribute-value relationship may be interpreted in column wise or in row wise. If the table tags in questions do not contain COLSPAN (ROWSPAN), the problem is easier. The first row and/or the first column consist of the attribute cells, and the others are valuc cells. Cell similarity guides us how to read a table. We define row (or column) similarity in terms of cell similarity as follows. Two rows (or columns) are similar if most of the corresponding cells between these two rows (or columns) are similar.

A basic table interpretation algorithm is shown below. Assume there are $\mathrm{n}$ rows and $\mathrm{m}$ columns. Let $c_{i j}$ denote a cell in $i^{\text {th }}$ row and $j^{\text {th }}$ column.

(1) If there is only one row or column, then the problem is trivial. We just read it in row wise or column wise.

(2) Otherwise, we start the similarity checking from the right-bottom position, i.c., $c_{\text {num }}$. That is, the $n^{\text {th }}$ row and the $\mathrm{m}^{\text {it }}$ column are regarded as base for comparisons.

(3) For cach row i $(1 \leq \mathrm{i}<\mathrm{n})$, compute the similarity of the two rows $i$ and $n$.

(4) Count how many pairs of rows are similar.

(5) If the count is larger than (n-2)/2, and the similarity of row 1 and row $n$ is smaller than the similarity of the other row pairs, then we say this table can be read in column wise. In other words, the first row contains attribute cells.

(6) The interpretation from row wise is done in the similar way. We start checking from $\mathrm{m}^{\text {th }}$ column, compare it with cach column $\mathrm{j}(1 \leq \mathrm{j}<\mathrm{m})$, and count how many pairs of columns arc similar.

(7) If neither "row-wise" nor "column-wise" can be assigned, then the default is set to "row wise".
Table 6 is an example. The first column contains attribute cells. The other cells are statistics of an experimental result. We read it in row wise. If COLSPAN (ROWSPAN) is used, the table interpretation is more difficult. Table 1 is a typical example. Five COLSPANs and two ROWSPANs are used to create a better layout. The attributes are formed hierarchically. The following is an example of hicrarchy.

$$
\begin{aligned}
& \text { Adult --.-- Price …-...-- Double Room } \\
& \text {-.-.-.- Single Room }
\end{aligned}
$$

Here, we extend the above algorithm to deal with table interpretation with COLSPAN (ROWSPAN). At first, we drop COLSPAN and ROWSPAN by duplicating scveral copies of cells in their proper positions. For example, COLSPAN $=3$ for "Tour Code" in Table 1, thus we duplicate "Tour Code" at columns 2 and 3. Table 7 shows the final reformulation of the example in Table 1. Then we employ the above algorithm with slight modification to find the reading direction.

The modification is that spanning cells are boundaries for similarity checking. Take Table 7 as an example. We start the similarity checking from the right-bottom cell, i.c., 360, and consider each row and column within boundaries. The cell "1999.04.01-2000.03.31" is a spanning cell, so that $2^{\text {nd }}$ row is a boundary. "Pricc" is a spanning cell, thus $2^{\text {nd }}$ column is a boundary. In this case, we can interpret the table tags in both row wise and column wise.

\begin{tabular}{|c|c|c|c|c|}
\hline Tour Code & $\begin{array}{l}\text { Tour } \\
\text { Code }\end{array}$ & Tour Code & DPOLAX01AB & DPOLAX01AB \\
\hline Valid & Valid & Valid & $\begin{array}{l}1999.04 .01- \\
2000.03 .31\end{array}$ & $\begin{array}{l}1999.04 .01- \\
2000.03 .31\end{array}$ \\
\hline $\begin{array}{c}\text { Class/ } \\
\text { Extension }\end{array}$ & $\begin{array}{c}\text { Class/ } \\
\text { Extension }\end{array}$ & $\begin{array}{c}\text { Class/ } \\
\text { Extension }\end{array}$ & $\begin{array}{l}\text { Economic } \\
\text { Class }\end{array}$ & Extension \\
\hline Adult & PRICE & $\begin{array}{l}\text { Single } \\
\text { Room }\end{array}$ & 35,450 & 2,510 \\
\hline Adult & PRICE & $\begin{array}{l}\text { Double } \\
\text { Room }\end{array}$ & 32,500 & 1,430 \\
\hline Adult & PRICE & Extra Bed & 30,550 & 720 \\
\hline Child & PRICE & Occupation & 25,800 & 1,430 \\
\hline Child & PRICL: & Extra Bed & 23,850 & 720 \\
\hline Child & P'RICE: & $\begin{array}{c}\text { No } \\
\text { Occupation }\end{array}$ & 22,900 & 360 \\
\hline
\end{tabular}

Table 7. Reformulation of Example in Table 1 
After that, a second cycle begins. The starting points are moved to new right-bottom positions, i.c., $(3,5)$ and $(9,3)$. In this cycle, boundaries are resel. The cells DPSLAXO1AB" and "Adule" ("Child") are spanning cells, so that $1^{\text {st }}$ row and $1^{\text {st }}$ column are new boundaries. At this time, "row-wise" is selected.

In final cycle, the starting positions are $(2,5)$ and $(9,2)$. The boundaries are $0^{\text {th }}$ row and $0^{\text {th }}$ column. These two sub-tables are read in row wisc.

\section{Presentation of Table Extraction}

The results of table interpretation are a sequence of attribute-value pairs. Consider the tour example. T'able 8 shows the extracted pairs. We can find the following two phenomena:

(1) A cell may be a value of more than one attributc.

(2) A cell maly act ats an attribute in one case, and at value in another case.

We can concatenate two attributes together by using phenomenon (1). For example, "35,450" is a value of "Single Room" and "IEconomic Class", thus "Single Room-liconomic Class" is formed. Besides that, we caln find attribute hicrarchy by using phenomenon (2). For example, "Single Room" is a value of "Price", and "Price" is a value of "Adult", so that we call create a hicrarchy "Adult-Price-Single Room".

Merging the results from these two phenomena, we can create the interpretations that we listed in Section 1. For example, from the two facts:

" 35,450 " is a value of "Single Room-Economic Class", and

"Adult-Price-Single Room" is a hicrarchical attribute,

we can infer that 35,450 is a value of "Adult-Price-Single Room-Economic Class".

In this way, we can transform unstructured data into more structured representation for further applications. Consider an application in question and answering. Given a query like "how much is the price of a double room for an adult", the keywords are "price", "double
Table 8 The Extracted $\Lambda$ ttribute-Value Pairs

\begin{tabular}{|c|c|c|}
\hline & Aluibule & Valluc \\
\hline \multirow{14}{*}{$1^{\text {st }}$ cycle } & Single Room & 35,450 \\
\hline & Single Room & 2,510 \\
\hline & I)ouble laoom & 32,500 \\
\hline & Double Room & 1,430 \\
\hline & $\ldots$ & $\ldots$ \\
\hline & No Oecupation & 22,900 \\
\hline & No Occupation & 360 \\
\hline & liconomic Class & 35,450 \\
\hline & licononic Class & 32,500 \\
\hline & $\begin{array}{l}\ldots \\
\text { liconomic Class }\end{array}$ & 22,900 \\
\hline & Extension & 2,510 \\
\hline & I:xtension & $1,4+30$ \\
\hline & $\cdots$ & $\ldots$ \\
\hline & Iixtension & 360 \\
\hline \multirow{7}{*}{$2^{m+1}$ cycle } & Class/lixtension & Economic Class \\
\hline & Class/lixtension & lixtension \\
\hline & Valid & $1900.004 .01-20000.03 .31$ \\
\hline & l'rice & Single Room \\
\hline & I'rice & Double Room \\
\hline & $\ldots$ & \\
\hline & IPRICL: & No Oecupration \\
\hline \multirow{4}{*}{$3^{n+1}$ eycle } & Four Code & DPOI AXOIANI \\
\hline & Valid & $1999.04 .01-2000.03 .31$ \\
\hline & Adult & Price \\
\hline & Child & Price \\
\hline
\end{tabular}

room", and "adult". After consulting the database learning from HTMI, texts, two values, 32,500 and 1,430 with attributes economic class and extension, are reported. With this table mining technology, knowledge that can be employed is beyond text level.

\section{Conclusion}

In this paper, we propose a systematic way to mine tables from HTML texts. Table filtering, table recognition, table interpretation and application of table extraction are discussed. The cues from HTML lags and information in table cells are employed to recognize and interpret tables. The F-measure for table 
recognition is $86.50 \%$.

There are still other spaces to improve performance. The cues from context of tables and the traversal paths of HTML pages may be also useful. In the text surrounding tables, writers usually explain the meaning of tables. For example, which row (or column) denotes what kind of meanings. From the description, we can know which cell may be an attribute, and along the same row (column) we can find their value cells. Besides that, the text can also show the semantics of the cells. For example, the table cell may be a monetary expression that denotes the price of a tour package. In this way, even money marker is not present in the table cell, we can still know it is a monetary expression.

Note that HTML texts can be chained through hyperlinks like "previous" and "next". The context can be expanded further. Their effects on table mining will be studied in the future. Besides the possible extensions, another research line that can be considered is to set up a corpus for evaluation of attribute-value relationship. Because the role of a cell (attribute or value) is relative to other cells, to develop answering keys is indispensable for table interpretation.

\section{References}

Appelt, D. and Israel, D. (1997) "Tutorial Notes on Building Information Extraction Systems," Tutorial on Fifth Conference on Applied Natural Language Processing, 1997.

Chen, H.H.; Ding Y.W.; and Tsai, S.C. (1998) "Named Entity Extraction for Information Retricval," Computer Processing of Oriental Languages, Special Issue on Information Retrieval on Oricntal Languages, Vol. 12, No. 1, 1998, pp.75-85.

Douglas, S.; Hurst, M. and Quinn, D. (1995) "Using Natural Language Processing for Identifying and Interpreting Tables in Plain Text," Proceedings of Fourth Annual Symposium on Document Analysis and Information Retrieval, 1995, pp. 535-545.

Douglas, S. and Hurst, M. (1996) "Layout and Language: Lists and Tables in Technical Documents," Proceedings of ACL SIGPARSE Workshop on Punctuation in Computational Linguistics, 1996, pp. 19-24.
Gaizauskas, R. and Wilks, Y. (1998) "Information Extraction: Beyond Document Retrieval," Computational Linguistics and Chinese Language Processing, Vol. 3, No. 2, 1998, pp. 17-59.

Green, E. and Krishmamoorthy, M. (1995) "Recognition of Tables Using Grammars," Proceedings of the Fourth Annual Symposium on Document Analysis and Information Retrieval, 1995, pp. 261-278.

Hurst, M. and Douglas, S. (1997) "Layout and Language: Preliminary Experiments in Assigning Logical Structure to Table Cells," Proceedings of the Fifth Conference on Applied Natural Language Processing, 1997, pp. 217-220.

Hurst, M. (1999a) "Layout and Language: Beyond Simple Text for Information Intcraction - Modeling the Table," Proceedings of the 2nd International Conference on Multimodal Interfaces, Hong Kong, January 1999.

Hurst, M. (1999b) "Layout and Language: A Corpus of Documents Containing Tables," Proceedings of AAAI Fall Symposium: Using Layout for the Generation, Understanding and Retrieval of Documents, 1999.

Mikheev, A. and Finch, S. (1995) " $\Lambda$ Workbench for Acquisition of Ontological Knowledge from Natural Text," Proceedingss of the 7th Conference of the European Chapter for Computational Linguistics, 1995, pp. 194-201.

MUC (1998) Proceedings of $7^{\text {th }}$ Message Understanding Conference, htp://www.muc.saic. $\mathrm{com} /$ proceedings/procecdings_index.html.

$\mathrm{Ng}$, H.T.; Lim, C.Y. and Koo, J.L.T. (1999) "Learning to Recognize Tables in Free Text," Proceedings of the 37th Annual Meeting of ACL, 1999, pp. 443-450. 